\title{
"Ceria"'
}

Jurnal Program Studi Pendidikan Anak Usia Dini

ISSN 2301-9905

Volume 10, No 2 Januari 2022

Fakultas Keguruan dan Ilmu Pendidikan - Universitas Muhammadiyah Tangerang

\section{PERAN ORANG TUA LAKI-LAKI TERHADAP KEMAMPUAN \\ EMOSI ANAK USIA 5-6 TAHUN DI PAUD MULYA PANTURA.}

\author{
${ }^{1}$ Nurul Fitria Kumala Dewi, ${ }^{2}$ Irmawati \\ ${ }^{1,2}$ Program Studi Pendidikan Guru Pendidikan Anak Usia Dini, Fakultas Keguruan Dan \\ Ilmu Pendidikan, Universitas Muhammadiyah Tangerang \\ Email : $\underline{\text { nurulfitriakd@gmail.com }}, \underline{2}$ Irmawatis2507@gmail.com
}

\begin{abstract}
ABSTRAK
Penelitian ini mendeskripsikan bagaimana peran orang tua laki-laki dalam mengembangkan emosi anak usia 5-6 tahun di Paud Mulya Pantura dan mendeskripsikan bagaimana kemampuan emosi anak usia 5-6 tahun di Paud Mulya Pantura. Adapun rumusan masalahnya Bagaimana Peran orang tua laki-laki terhadap perkembangan emosi anak usia 5-6 tahun di Paud Mulya Pantura, Bagaimana kemampuan Emosi Anak Usia 5-6 Tahun di Paud Mulya Pantura, Bagaimana Peran Orang Tua Laki-Laki Terhadap Kemampuan Emosi Anak Usia 56 Tahun Di Paud Mulya Pantura. Pendekatan ini menggunakan pendekatan kualitatif. Teknik pengumpulan data melalui observasi, wawancara dan dokumentasi. Analisis data yaitu bersifat Studi Kasus. Hasil penelitian ini dapat disimpulkan bahwa dari ketiga subjek tersebut peneliti melihat bahwa anak memiliki kesamaan yaitu mudah marah dan menangis meskipun alasannya berbeda-beda : (1) Subjek IR akan marah ketika hasil karya temannya lebih bagus dari pada miliknya. (2) Subjek FD akan marah ketika barang miliknya dipegang orang lain. (3) Subjek DL merasa takut jika tidak ada ibu disampingnya. Dari ketiga anak tersebut ketika marah atau menangis anak akan sulit dikendalikan maka perlu adanya bantuan dari orang dewasa yang berada disekitarnya. Hal tersebut berkaitan dengan kemampuan emosi anak atas landasan mengenal diri sendiri dalam emosi.Peneliti melihat dari ketiga anak tersebut memiliki kesamaan lain yaitu ayah yang memiliki pekerjaan yang menyita banyak waktu.oleh karna itu ayah akan jarang berada dirumah dan berinteraksi dengan anak, Sehingga anak tidak memiliki banyak waktu dengan ayah.Meskipun demikian ayah tetap memberikan nasihat mengenai perilaku anak, dan memberikan contoh agar dapat dijadikan panutan oleh anak seperti memberikan arahan serta nasihat kepada anak ketika melakukan kesalahan.
\end{abstract}

Kata Kunci: Ayah, Emosi , Anak Usia Dini 


\section{Pengantar}

Anak Usia Dini yaitu anak yang berada dalam rentang usia 0-6 tahun. Pada usia ini merupakan masa keemasan ( golden age), artinya pada saat iini anak berada dalam masa sensitif yakni masa yang sangat mudah untuk menerima rangsangan pengetahuan dan kemampuan yang sesuai dengan tahapan tumbuh kembang sejak dini. Oleh karena itu stimulasi yang tepat dan berkesinambungan butuh diberikan agar tumbuh kembang anak dapat berjalan dengan optimal. Stimulasi ini dapat diberikan oleh suatu lembaga pendidikan salah satunya melalui Pendidikan Anak Usia Dini (PAUD). Hal tersebut dipertegas dalam Undang-Undang Nomor 20 Tahun 2003 tentang sistem Pendidikan Nasional (SISDIKNAS) pada pasal 14 ayat 1 Pendidikan Anak Usia Dini (PAUD) merupakan upaya pembinaan yang ditujukan kepada anak sejak lahir sampai dengan usia enam tahun yang dilakukan melalui pemberian rangsangan pendidikan untuk membantu tumbuh kembang jasmani dan rohani agar anak memiliki kesiapan dalam memasuki pendidikan lanjutan (Mahmud, 2019).

Ayah adalah sosok yang penting dalam keluarga yang dapat menentukan segala kebutuhan anak. Ayah yang baik mampu memberikan sifat positif dalam pengasuhan melalui aspek efektif, kognitif dan perilaku. Keterlibatan dalam pengasuhan diartikan sebagai perbandingan usaha- usaha yang dilakukan seorang ayah dalam memikirkan, merencanakan, merasakan, memperhatikan, memantau, mengevaluasi, dan mengkhawatirkan anak keterlibatan ayah dikaitkan dengan tersedianya kesempatan bagi anak untuk mengaplikasikan suatu pengasuhan, dorongan dan rasa nyaman.

Peran ayah bagi anak menjadikan hari-hari anak lebih bermakna, membagikan inisiatif serta kehangatan kasih sayang keluarga. Sosok ayah sangat dibutuhkan dalam suatu keluarga tidak hanya sebagai pemimpin sosok ayah pula sebagai contoh serta keteladanan untuk anak- anaknya. ayah tidak hanya dibutuhkan oleh anak laki-laki, tetapi anak perempuan juga perlu dekat dengan ayah agar dapat mendidik anak perempuan untuk berpikir lebih rasional.Sementara itu selain mengajarkan sikap rasional ayah juga mengajarkan sikap keberanian dalam kepemimpinan.

Gottman \& DeClaire mengemukakan bahwa keterlibatan ayah akan mengembangkan kemampuan anak untuk berempati penuh kasih sayang dan perhatian 
serta hubungan sosial yang lebih baik. Ketika anak-anak berada disekolah mereka dengan mudah bergaul bersama teman seusianya dan dirumah anak-anak juga dapat berbaur dengan baik. Selain mudah bersosialisasi, anak juga memiliki keterampilan dalam berbicara serta mengemukakan pendapat. Peran ayah mempengaruhi pemahaman gender pada anak. Anak laki-laki yang dekat dengan ayahnya sifat maskulin akan nampak ketika dilihat (Dinda Septiani, 2017, p. 122). Ayah memiliki peranan yang tidak kalah penting, selain ibu. Menjalin hubungan erat dengan ayah akan memberikan pemahaman jenis kelamin pada anak-anak, bagi anak laki-laki akan memunculkan sikap berani dan jantan.

Peran ayah bukan hanya memiliki ayah atau tidak memiliki ayah. Melainkan kehadiran ayah serta partisipasi dalam keluarga. Anak yang memiliki ayah namun sibuk bekerja dianggap juga tidak memiliki figur ayah. karena yang dibutuhkan anak adalah hadirnya perasaan hangat serta kasih sayang yang diberikan ayah kepadanya. Ayah yang sibuk bekerja menyebabkan anaknya kehilangan ayah, atau yang disebut yatim. Tanpa ayah adalah tidak adanya peran dan sosok ayah dalam kehidupan seorang anak. konsekuensi menjadi yatim bagi anak-anak adalah harga diri yang rendah, perasaan marah, kesepian, cemburu dan malu. Perkembangan tersebut itu kemudian mempengaruhi kehidupan anakanak.

Berdasarkan pendapat ahlii tersebut tentunya menjelaskan betapa pentingnya peran ayah dalam tumbuh kembang anak .ayah yang terlibat dalam memberikan pengasuhan akan memenuhi kebutuhan anak, baik secara fisik, psikologis maupun emosional. Menurut (Mahyuddin, 2017) Emosi adalah suatu suasana yang mempengaruhi perasaan/pikiran yang ditandai dengan perubahan biologis dan muncul sebelum atau sesudah terjadinya perilaku. Mekanisme terjadinya emosi diawali dengan suatu peristiwa (situasi) yang mengaktifkan sistem saraf sehingga menyebabkan perubahan fisiologis di luar kesadaran (misalnya perubahan ekspresi wajah, percepatan detak jantung, berkeringat, dan sebagainya) yang akhirnya membuat seseorang mengalami kenyamanan dan ketidaknyamanan sesuai dengan rangsangan.

Perkembangan emosi meliputi kemampuan anak untuk mencintai, merasa nyaman, berani, bahagia, takut, marah, dan bentuk emosi lainnya. Dalam aspek ini, anak sangat dipengaruhi oleh interaksi orang tua dan orang di sekitarnya. Emosi berkembang sesuai dengan rangsangan emosional yang diterimanya.Maka karenanya anak yang menerima 
curahan kasih sayang akan belajar untuk mencintai.

\section{Metode}

Dalam penelitian ini menggunakan pendekatan penelitian kualitatif yang digunakan untuk meneliti kondisi objek yang dialami, dimana peneliti adalah sebagai instrumen itu sendiri. Bogman dan Taylor (1975:5) mengemukakan bahwa metode kualitatif merupakan prosedur penelitian yang menghasilkan data deskriptif berupa kata-kata tertulis maupun lisan dari orang-orang yang diamati (Moleong, 2017, p. 4).

Adapun jenis metode yang digunakan dalam penelitian ini adalah pendekatan studi kasus. Menurut Cresswell (2008) penelitian studi kasus adalah suatu pendekatan penelitian kualitatif, yang dilakukan dengan cara mengeksplor sebuah kasus atau beberapa kasus, di mana di dalam pengumpulan data dilakukan secara terperinci melalui observasi, wawancara, dokumen dan materi audiovisual atau laporan dari sebuah kasus yang didasarkan tema atau topik tertentu (Sulaeman, 2016). Melalui metode ini, peneliti berusaha meneliti secara jelas dan terperinci mengenai peran orang tua laki-laki terhadap kemampuan emosi anak usia 5-6 tahun di Paud Mulya Pantura. Teknik analisis data menggunakan model Miles dan Huberman yang terdiri dari tiga tahap yaitu 1: Pengumpulan Data (Data collection) 2 : Reduksi Data (Data Reduction) 3: Penyajian Data (Display Data ).

\section{Hasil dan Pembahasaan}

Berdasarkan hasil penelitian yang telah dilaksanakan serta dapat tertuang dalam hasil dan pembahasa maka dari Penelitian Peran Orang Tua Laki-Laki Terhadap Kemampuan Emosi Anak Usia 5-6 Tahun Di Paud Mulya Pantura. Hasil dari pembahasan yang dikemukakan peneliti yakni dari ketiga subjek tersebut peneliti melihat bahwa anak memiliki kesamaan yaitu mudah marah dan menangis meskipun alasannya berbeda-beda : (1) Subjek IR akan marah ketika hasil karya temannya lebih bagus dari pada miliknya. (2) Subjek FD akan marah ketika barang miliknya dipegang orang lain. (3) Subjek DL merasa takut jika tidak ada ibu disampingnya. Dari ketiga anak tersebut ketika marah atau menangis anak akan sulit dikendalikan maka perlu adanya bantuan dari orang dewasa yang 
berada disekitarnya. Hal tersebut berkaitan dengan kemampuan emosi anak atas landasan mengenal diri sendiri dalam emosi.

Peneliti melihat dari ketiga anak tersebut memiliki kesamaan lain yaitu ayah yang memiliki pekerjaan yang menyita banyak waktu.oleh karna itu ayah akan jarang berada dirumah dan berinteraksi dengan anak, Sehingga anak tidak memiliki banyak waktu dengan ayah. Meskipun demikian ayah tetap memberikan nasihat mengenai perilaku anak, dan memberikan contoh agar dapat dijadikan panutan oleh anak seperti memberikan arahan serta nasihat kepada anak ketika melakukan kesalahan.

\section{Kesimpulan}

Berdasarkan analisis data yang dilakukan maka dapat diambil kesimpulan antara lain dari ketiga subjek tersebut peneliti melihat bahwa anak memiliki kesamaan yaitu mudah marah dan menangis meskipun alasannya berbeda-beda : (1) Subjek IR akan marah ketika hasil karya temannya lebih bagus dari pada miliknya. (2) Subjek FD akan marah ketika barang miliknya dipegang orang lain. (3) Subjek DL merasa takut jika tidak ada ibu disampingnya. Dari ketiga anak tersebut ketika marah atau menangis anak akan sulit dikendalikan maka perlu adanya bantuan dari orang dewasa yang berada disekitarnya hal tersebut dikarenakan ayah yang memiliki pekerjaan yang menyita banyak waktu.oleh karna itu ayah akan jarang berada dirumah dan berinteraksi dengan anak.

\section{DAFTAR PUSTAKA}

Abd, M. D. N. F. E. T. (2019). Perkembangan Sosial Emosional Anak Usia Dini (Ke 1). Grup Penerbitan CV BUDI UTAMA.

Aisyah, D. S., Riana, N., \& Putri, F. E. (2019). Peran Ayah (Fathering) Dalam Perkembangan Sosial Anak Usia Dini (Studi Kasus pada Anak Usia 5-6 tahun di RA Nurhalim Tahun Pelajaran 2018). Jurnal Wahana Karay Ilmiah_Pascasarjana (S2) PAI Unsika, 3(1), 294-304.

Aryanti, Y. (2017). Peran ayah dalam pengasuhan anak usia dini. Jurnal Pendidikan Dompet Dhuafa, 7(1), 21-24.

Dinda Septiani, I. N. N. (2017). Peran Keterlibatan Ayah dalam Pengasuhan Bagi Perkembangan Kecerdasan Moral Anak The Role of Dad 's Involvement in Parenting Development of Moral Intelligence of Children. 13(2), 124-125. 
Filtri, H. (2017). PERKEMBANGANEMOSIONAL ANAK USIA DINI USIA 5-6 TAHUN DITINJAU DARI IBU YANG BEKERJA Title. PAUD Lectura: Jurnal Pendidkan Anak Usia Dini, 1(1), 32-37.

Giantara, F., Kusdani, K., \& Afrida, S. (2019). Peran Ayah Dalam Pendidikan Keluarga Di Kota Pekanbaru. Jurnal Review Pendidikan Dan Pengajaran, 2(2), 234-245. https://journal.universitaspahlawan.ac.id/index.php/jrpp/article/view/459\%0Ahttps:/jo urnal.universitaspahlawan.ac.id/index.php/jrpp/article/download/459/558

Herianto, H., Yarmani, Y., Sutisyana, A., \& Defliyanto, D. (2018). Analisis Kemampuan Open Spike Pada Siswa Putra Ekstrakurikuler Bola Voli Di Smpn 18 Kota Bengkulu. Kinestetik, 2(2), 160-165. https://doi.org/10.33369/jk.v2i2.6713

Isabella Hasiana, A. W. (2017). Pengaruh Musik dalam Mengembangkan Kemampuan Mengenal Bilangan Siswa Kelompok A di TK Lintang Surabaya. Jurnal Obsesi: Jurnal Pendidikan Anak Usia Dini, 1(2), 118. https://doi.org/10.31004/obsesi.v1i2.23

Mahmud, B. (2019). Urgensi Stimulasi Kemampuan Motorik Kasar Pada Anak Usia Dini. DIDAKTIKA: Jurnal Kependidikan, 72(1), 76-87. https://doi.org/10.30863/didaktika.v12i1.177

Mahyuddin, N. (2017). Emosional Anak Usia Dini (ke-1). PRENADAMEDIA GROUP.

Martha, K., \& Kurniati, N. M. T. (2018). EFEKTIVITAS TERAPI PEMAAFAN DENGAN MODEL PROSES DARI ENRIGHT UNTUK MEMBANTU REMAJA KORBAN PERCERAIAN DALAM MEMAAFKAN ORANG TUA. Jurnal Psikologi, 11(1), 10-24. https://doi.org/10.35760/psi.2018.v11i1.2070

Moleong, L. (2017). Metodologi Penelitian Kualitatif(Ke-1). PT REMAJA ROSDAKARYA.

Mulyana, E. H., Gandana, G., \& Muslim, M. Z. N. (2017). Kemampuan Anak Usia Dini Mengelola Emosi Diri Pada Kelompok B Di Tk Pertiwi Dwp Kecamatan Tawang Kota Tasikmalaya. Jurnal Paud Agapedia, 1(2), 214-232. https://doi.org/10.17509/jpa.v1i2.9361

Muzaqi. (2019). OPTIMALISASI PERAN AYAH DALAM PENGASUHAN ANAK DIRUMAH DAN DISEKOLAH. 21(2), 31-51.

Nurhasanudin, T. S. (2021). PENDEKATAN SENTRA BERMAIN PERAN UNTUK MENINGKATKAN KECERDASAN SOSIAL EMOSIONAL ANAK USIA DINI. Journal of Community Education, 2, 38-42.

Simamora, N., Ulva, M., \& Sihombing, S. (2017). Peranan Komunikasi Antar Pribadi Dalam Kepuasan Berikteraksi di Kalangan Mahasiswa Fakulitas Ekonomi dan Ilmu Sosial USM- INDONESIA Program Studi Ilmu Komunikasi Universitas Sari mutiara Indonesia. Jurnal Lensa Mutiara Komunikasi, Vol 1, 55-66. 
"Ceria"

Sondakh, E. B. W. M., \& Pasoreh, Y. (2019). Peranan komunikasi dalam menyosialisasikan bantuan dana pendidikan kepada masyarakat suku Kamoro ( Studi pada lembaga musyawarah adatsuku Kamoro di Timika Papua ). Acta Diurna, 8(2), 68-70.

Sri Lestari, N. A. (2020). Peran Ayah Sebagai Orangtua Tunggal Dalam Pengasuhan Anak. Sains Psikologi, 9(1), 1-14.

Sugiyono. (2019). Metode Penelitian Kuantitatif,kualitatif,dan RED (Ke 27). Alfabeta.

Sulaeman. (2016). Metodologi Penelitian Pendididikan 